\title{
Allelopathic Activity of the Iron Chelator Anachelin - A Molecular Hybrid with a Dual Mode of Action
}

De Sarkar, Suman ; Blom, Judith F ; Bethuel, Yann ; Jüttner, Friedrich ; Gademann, Karl

\begin{abstract}
One of the compounds suggested to be responsible for the cyanobacterial dominance over competing green algae is identified. Evidence is provided on the molecular, chemical level that the iron chelator anachelin from the cyanobacterium Anabaena cylindrica promotes both the growth of cyanobacteria and reduces the growth of competing chlorophytes. These results illustrate a molecular strategy of addressing two challenges (nutrient availability and algal competition) by one molecule. Such strategies could be implied in harmful algal blooms in marine and freshwater environments.
\end{abstract}

DOI: https://doi.org/10.1002/hlca.201600123

Posted at the Zurich Open Repository and Archive, University of Zurich

ZORA URL: https://doi.org/10.5167/uzh-134797

Journal Article

Accepted Version

Originally published at:

De Sarkar, Suman; Blom, Judith F; Bethuel, Yann; Jüttner, Friedrich; Gademann, Karl (2016). Allelopathic Activity of the Iron Chelator Anachelin - A Molecular Hybrid with a Dual Mode of Action. Helvetica Chimica Acta, 99(10):760-773.

DOI: https://doi.org/10.1002/hlca.201600123 


\title{
Allelopathic Activity of the Iron Chelator Anachelin - A Molecular Hybrid with a Dual Mode of Action
}

\author{
Suman De Sarkar, ${ }^{\text {a) }}$ Judith F. Blom, ${ }^{\text {b) }}$ Yann Bethuel, ${ }^{c)}$ Friedrich Jüttner, ${ }^{\text {b) }}$ and \\ Karl Gademann $\left.{ }^{\star}, \mathrm{a}, \mathrm{c}, \mathrm{d}, \mathrm{e}\right)$ \\ a) Department of Chemistry, University of Basel, St. Johanns-Ring 19, CH-4056 Basel, \\ Switzerland \\ $\left.{ }^{b}\right)$ Limnological Station, Institute for Plant and Microbial Biology, University of Zurich, Seestr. 187, \\ $\mathrm{CH}-8802$ Kilchberg, Switzerland \\ $\left.{ }^{c}\right)$ Laboratorium für Organische Chemie, Swiss Federal Institute of Technology (ETH) Zürich, \\ Vladimir-Prelog-Weg 1-5/10, CH-8093 Zürich, Switzerland \\ $\left.{ }^{d}\right)$ Chemical Synthesis Laboratory (SB-ISIC-LSYNC), Swiss Federal Institute of Technology \\ (EPFL), CH-1015 Lausanne, Switzerland \\ e) Department of Chemistry, University of Zurich, Winterthurerstrasse 190, CH-8057 Zürich, \\ Switzerland
}

email: karl.gademann@uzh.ch

\begin{abstract}
One of the compounds suggested to be responsible for the cyanobacterial dominance over competing green algae is identified. Evidence is provided on the molecular, chemical level that the iron chelator anachelin from the cyanobacterium Anabaena cylindrica promotes both the growth of cyanobacteria and reduces the growth of competing chlorophytes. These results illustrate a molecular strategy of addressing two challenges (nutrient availability and algal competition) by one molecule. Such strategies could be implied in harmful algal blooms in marine and freshwater environments.
\end{abstract}

Keywords: Natural Products - Organic Synthesis - Siderophores - Chemical Ecology - Mechanism of Action

Supporting information for this article is given via a link at the end of the document.

\section{Introduction}

The growth of phytoplankton has direct implications to fields such as global carbon budgeting, climate regulation and for fisheries through its central role in both marine and freshwater ecosystems.[1] The growth of prokaryotic cyanobacteria and eukaryotic algae is determined by resource limitations including light, inorganic and organic nutrients, the attack of grazers and pathogens, and interspecific inhibition through allelochemicals.[2] The importance of phosphorous and nitrogen has been well documented, and recently also the impact of iron on phytoplankton growth has found new interest.[3-5] Whereas iron is one of the most abundant elements on earth, its bioavailability is very low due to the prevalence of insoluble iron oxide hydrate species.[6,7] 
Cyanobacteria have met this challenge by producing small molecule iron chelators called siderophores.[8-10] Over sixty years ago, Fogg and Westlake suggested that cyanobacteria secrete siderophores that "may have important effects on the growth of organisms in the water".[11] This hypothesis was expanded by Tassigny and Lefèvre, who raised the possibility of allelochemical action of such secreted compounds in cyanobacterial and algal blooms.[12]

Murphy and co-workers,[13] and more recently Matz and co-workers,[14] provided further experimental support and concluded that the excretion of siderophores by species of the cyanobacterium Anabaena enables other cyanobacteria to grow, to outcompete, and thus to dominate eukaryotic algae. So far only supernatants of cultures or crude extracts were studied.[11-14] In particular, the presence of additional unrelated allelopathic compounds was never ruled out and the responsible compounds were never characterized on the molecular level.

Anachelin (1) was isolated from the cyanobacterium Anabaena cylindrica and features an interesting structural diversity combining polyketide, peptide and alkaloid fragments (Figure 1).[15] We have studied its conformation,[16] suggested a biogenetic hypothesis[17] and established the configuration by total synthesis.[18] However, up to now, no biological studies of this metabolite have been reported. In particular, while the catecholate unit (green in 1) is proposed to facilitate iron uptake and can be used to functionalize surfaces, the role of the polyketide fragment (red in 1) remained unknown.

Herein, we provide evidence through chemical synthesis combined with growth experiments that the cyanobacterial siderophore anachelin (1)[15] enhances growth of the cyanobacterium Microcystis aeruginosa concomitant with allelopathic activity against the competing green alga Kirchneriella contorta. We devised a new synthetic route based on several organocatalytic transformations to the polyketide fragment of anachelin, and through the synthesis of additional derivatives, the structural elements in anachelin (1) that are responsible for this dual mode of action have been identified. Anachelin (1) thus presents a fully elucidated example of a cyanobacterial siderophore with allelopathic properties against competing photoautotrophic microorganisms (dual mode of action).

\section{Results and Discussion}

Synthesis: In order to study the effects of the constitution and configuration of anachelin (1) on biological activity, anachelin (1), three truncated derivatives 2-4 and two epimers 5 and 6 Figure 1) were prepared by chemical synthesis. As a representative of the alkaloid fragment, Bocprotected anachelin chromophore $\mathbf{2}$ was prepared in 8 steps starting from L-dopa using an oxidative aza-annulation as the key step.[17,19] The peptide fragment 3 was synthesized by debenzylation of a protected analog previously reported by us.[18] In order to block the otherwise free terminal amino group and mask unwanted reactivity, the chemically inert butyloxycarbonyl (Boc) group was introduced in fragments 2 and 3 . The preparation of diastereoisomers 5 and $\mathbf{6}$ was carried out using previously reported building blocks.[18]
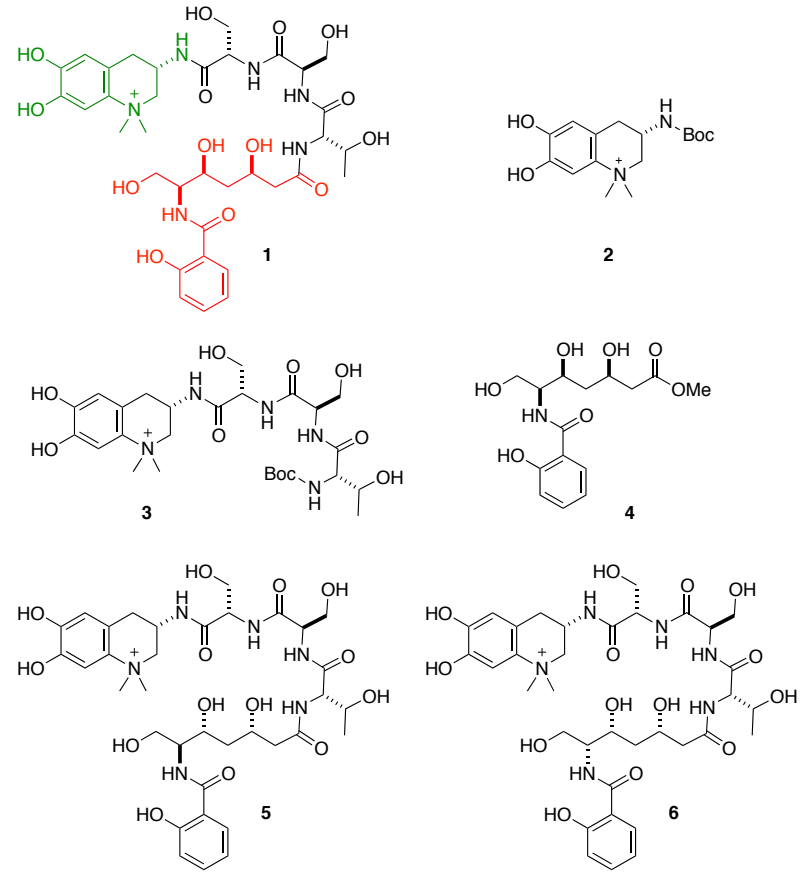

Figure 1. Anachelin (1), fragments 2-4, and diastereoisomers $\mathbf{5}$ and $\mathbf{6}$. 

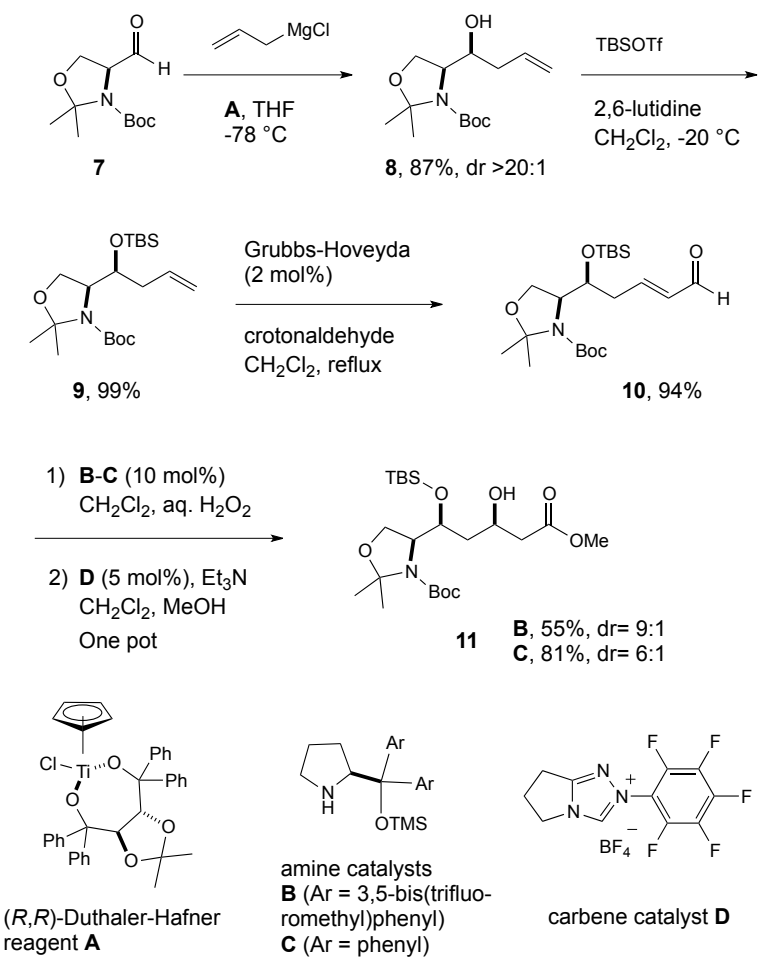

Scheme 1. The organocatalytic approach to the polyketide fragment 4.

The polyketide fragment 4 was addressed next, and although we have developed routes to this unit,[18,19] we needed an optimized process to secure amounts for biological testing. Therefore, a concise approach featuring organocatalytic key steps was developed for the synthesis of the challenging polyketide fragment 4 . The synthesis commenced with the addition of allylmagnesium chloride to Garner's aldehyde (7)[20] (Scheme 1). Unfortunately, the chiral substrate was unable to induce good selectivity in the addition step and 3:1 mixture was obtained in favor of desired diastereoisomer. Thus, we utilized the reliable Duthaler-Hafner method that results excellent yield and selectivity for the allyl alcohol $8(87 \%$, $\mathrm{dr}>20: 1$ ).[21] The chiral allyl alcohol 8 was then protected, and silylated 9 was subjected to cross metathesis with crotonaldehyde to the $\alpha, \beta-$ unsaturated aldehyde 10 in good yield (93\% over two steps). We then envisioned the use of an organocatalytic approach for the installation of the $\beta$-hydroxy group and oxidation of the aldehyde to the ester.[22] In the first step, a catalyst controlled asymmetric epoxidation was performed with the proline-derived secondary amine catalysts B and C.[23] Sterically demanding catalyst $\mathbf{B}$ resulted in good selectivity with moderate yield, whereas slightly diminished selectivity but good yield was obtained with biphenyl-substituted catalyst $\mathbf{C}$. The chiral epoxy aldehyde was then directly subjected to the $\mathrm{N}$ heterocyclic carbene $(\mathrm{NHC})$ catalyzed internal redox process in the same pot.[24] In situ generated $\mathrm{NHC}$ by deprotonation of corresponding azolium ion D facilitates the epoxide opening followed by esterification to yield ester $\mathbf{1 1}$ in good yield and selectivity.

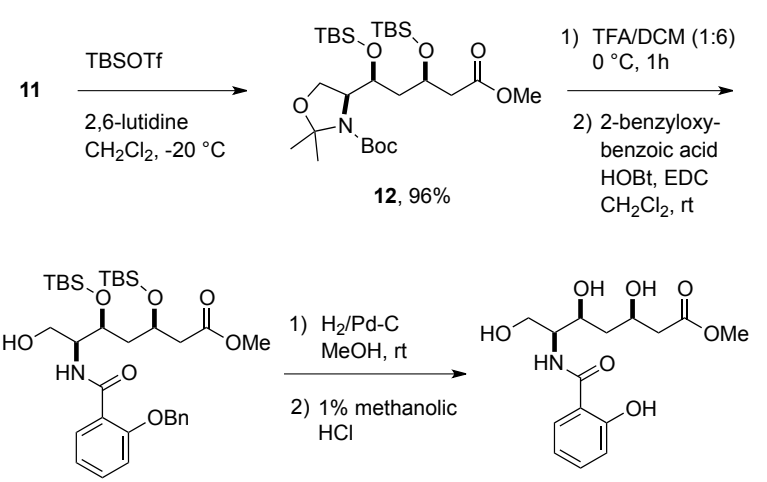

13, $75 \%$ over two steps

4, $99 \%$ over two steps

Scheme 2. Completion of the synthesis of polyketide fragment 4.

We then proceeded with the synthesis and silyl protection of the free $\mathrm{OH}$ group, which delivered the fully protected ester 12 (Scheme 2). The next task was the introduction of the amide functionality after selective deprotection of Bocgroup. After some unsuccessful attempts using Lewis acids $\left(\mathrm{AlCl}_{3}\right)$ or stronger Brønsted acids $(\mathrm{HCl})$, it was found that both the acetonide and Boc group can be cleaved using a mixture of $\mathrm{CH}_{2} \mathrm{Cl}_{2}$ and $\mathrm{CF}_{3} \mathrm{CO}_{2} \mathrm{H}$ at $0{ }^{\circ} \mathrm{C}$ for $1 \mathrm{~h}$. Undesired, desilylated product formation was observed by carrying out the reaction at higher temperature and upon longer reaction time. The amino alcohol was then subjected to amide coupling employing $E D C \cdot \mathrm{HCl}$ and $\mathrm{HOBt}$ as coupling reagents to give 13. Finally, removal of the protecting groups by sequential hydrogenation and acid mediated desilylation completed the synthesis of target compound 4 in 9 steps and $40 \%$ overall yield 
starting from Garner's aldehyde. This route therefore allowed for the generation of sufficient material for subsequent biological testing, which was carried out next.

Effect of Anachelin on Growth of Microcystis aeruginosa: We first wanted to evaluate the effect of the siderophore anachelin (1) on the growth of other cyanobacteria. Therefore, we investigated the growth inducing properties of anachelin (1), the siderophore of Anabaena cylindrica,[15] on a bloom-forming cyanobacterium (Microcystis aeruginosa). We prepared synthetic anachelin,[18] which was shown to be spectroscopically identical to a natural sample and, in particular, free of any cyanobacterial toxins potentially associated with natural samples. The addition of anachelin (1) promoted growth of the toxic cyanobacterium $M$. aeruginosa in a dose-dependant manner (Figure 2). Small amounts of anachelin (starting at 800 $\mathrm{nM}$ concentration) were sufficient to lead to a significant higher growth compared to the control.

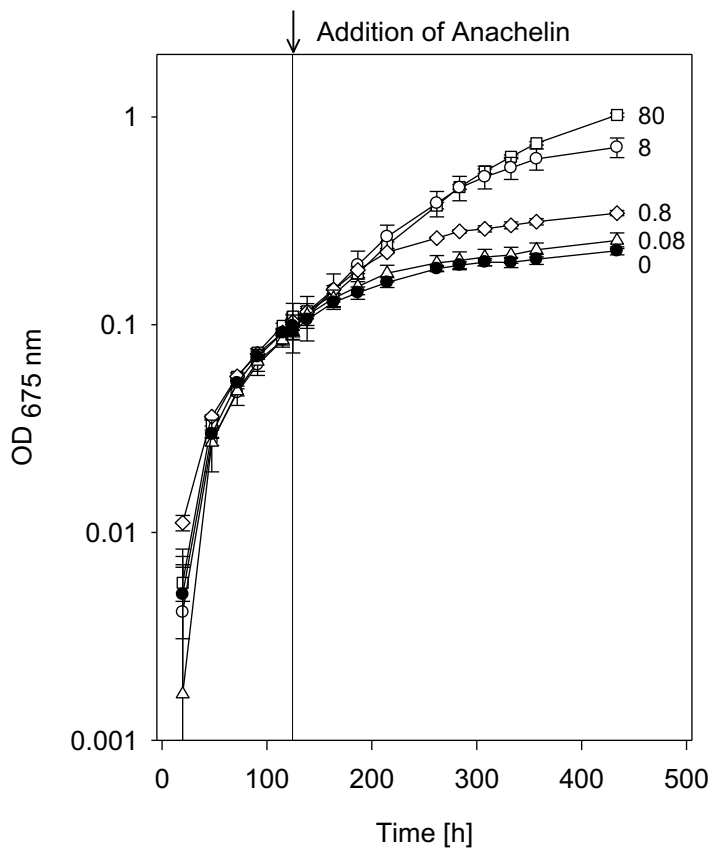

Figure 2. Growth of Microcystis aeruginosa (grown in $0.1 \mu \mathrm{M}$ Fe-citrate) before and after addition of anachelin (1). Anachelin was added in 4 different concentrations $(0.08 ; 0.8 ; 8 ; 80 \mu \mathrm{M})$ at $124.5 \mathrm{~h}$. Error bars indicate the standard deviation of three replicates.
Having established a positive impact of anachelin (1) on $M$. aeruginosa, we wanted to investigate a variety of concentrations of both siderophore and $\mathrm{Fe}$ (Figure 3). This beneficial effect on cyanobacterial growth was further substantiated at two different $\mathrm{Fe}$ concentrations in the medium $(0.1 \mu \mathrm{M}$ and $10 \mu \mathrm{M})$, but the observed effects decreased with increasing iron concentration (Figure $3 \mathrm{~A}$ and $3 \mathrm{~B}$ ), likely due to higher growth rates of $M$. aeruginosa. Whereas at lower iron concentration an almost fivefold increase in growth compared to control could be observed, the increase at higher iron concentrations in the medium was only twofold. The reason for this growth enhancing property is likely to reside in the binding of iron by the siderophore resulting thus in higher bioavailability of iron to the cyanobacterium. $M$. aeruginosa itself is known to produce hydroxamate-type siderophores.[25] However, the phenomenon that microbes can uptake siderophores they do not produce by themselves is well known and was described as 'siderophore piracy'.[26] In addition, it could be demonstrated that uncultured bacteria were enabled to grow via the secretion of siderophores of a distantly related and previously cultured bacterium.[27] Additionally, it was shown that within the genome of some bacteria the number of siderophore uptake genes is much higher than the number of synthesis genes.[28] From all these findings it can be concluded that the inability to produce siderophores and thus the dependence on other organisms might allow microbial growth to establish a community only in an environment with favored neighbours.[27] Although only known from heterotrophic bacteria so far, a similar 'siderophore piracy' might also take place in cyanobacteria. Still it is unknown whether the iron-anachelin complex delivers iron directly or through a specific transporter into the Microcystis cell. However, it seems that $M$. aeruginosa is a strong competitor under iron limitation.[25]

In a first conclusion, these experiments demonstrate that anachelin (1) is not only able to enhance growth of its producer,[15] but also to enhance growth of other cyanobacteria such as M. aeruginosa, likely via facilitated Fe uptake by chelation. 


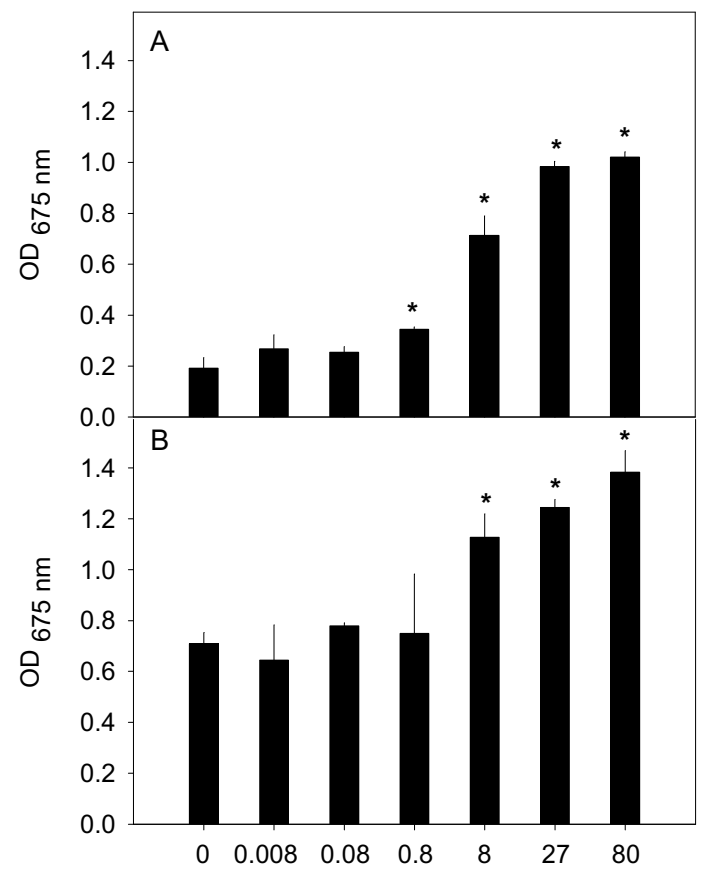

Anachelin $[\mu \mathrm{M}]$

Figure 3. Growth of the cyanobacterium Microcystis aeruginosa $310 \mathrm{~h}$ after addition of six different concentrations of anachelin (1). Error bars indicate the standard deviation of three replicates. Asterisks above bar indicate that the concentration of anachelin significantly promoted the growth of $M$. aeruginosa compared to the control ( $p<0.05$; tested by ANOVA, followed by Dunnett's post hoc tests). (A) $M$. aeruginosa grown in $0.1 \mu \mathrm{M}$ Fe-citrate; (B) $M$. aeruginosa grown in $10 \mu \mathrm{M}$ Fe-citrate.

Effect of Anachelin (1) on Growth of Kirchneriella contorta: We then investigated the action of anachelin on a competing planktonic green algae (chlorophyte, Kirchneriella contorta). Anachelin (1) inhibited the growth of this species in a dose-dependant manner, starting at nanomolar concentrations; a significant impact could be observed at low micromolar concentrations (Figure 4). This effect was not due to iron sequestering by anachelin, as this allelopathic effect was also found to be present at a large excess of iron: at $10 \mu \mathrm{M}$ total $\mathrm{Fe}$ (III) concentration, nanomolar concentrations of anachelin were sufficient to negatively impact the growth of the green algae (Figure 4). A growth reduction of $15 \%$ was already observed at 900 $\mathrm{nM}$ concentrations; at $60 \mu \mathrm{M}$ a growth reduction of $33 \%$ was found. From these experimental data, it can be concluded that this allelopathy is most likely independent of iron concentration, thus questioning the 'iron monopoly' hypothesis,[13] and adding support to the hypothesis of additional inhibitory activity unrelated to iron chelation. Matz and co-workers could show that siderophores derived from Anabaena flos-aquae inhibited the growth of the green alga Chlamydomonas reinhardtii via uncharacterized toxicity in iron-limited medium but not due to competition of iron.[14] Additionally, we observed a significant growth inhibitory effect of anachelin against Chlamydomonas which reflects its general allelopathic activity (see supporting information).

Taken together, these results provide evidence that anachelin (1) is able to promote the growth of the cyanobacterium $M$. aeruginosa, and that this natural product inhibits the growth of two competing green algae. Such a dual mode of action for an iron chelator is surprising. We then wanted to evaluate the structural requirements for these effects, and in particular, find out if certain fragments of anachelin (1) were responsible for this divergent activity.

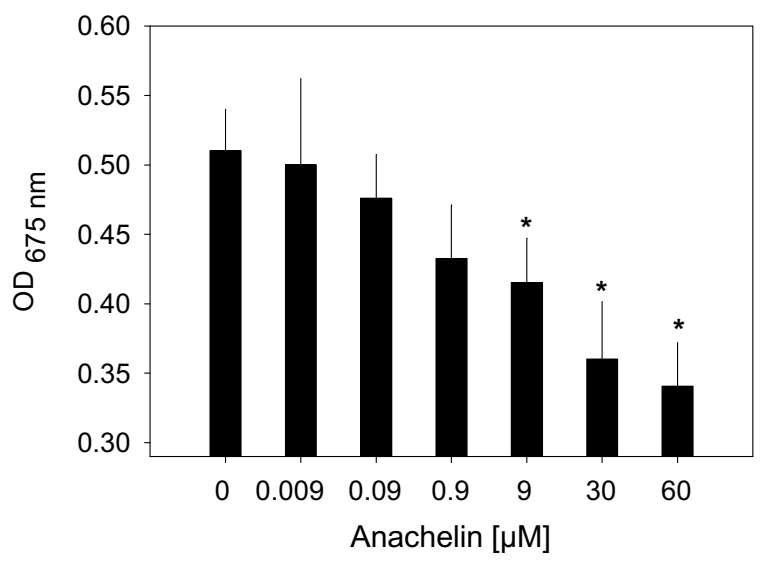

Figure 4. Reduction of growth of the green alga Kirchneriella contorta $316 \mathrm{~h}$ after addition of six different concentrations of anachelin (1). K. contorta was grown in $10 \mu \mathrm{M} \mathrm{Fe-citrate.} \mathrm{Error} \mathrm{bars} \mathrm{indicate} \mathrm{the}$ standard deviation of three replicates. Asterisks above bar indicate that the concentration of anachelin 
significantly inhibited the growth of $K$. contorta compared to the control ( $p<0.05$; tested by ANOVA, followed by Dunnett's post hoc tests).

Effect of Fragments on Growth of Kirchneriella contorta: In order to investigate the chemical mode of action of this allelopathic activity, and to identify the structural requirements, derivatives 2-4 of anachelin (1) were tested for the growth inhibition of $K$. contorta (Figure 5). First we investigated the role of the quaternary ammonium functionality, which is known for manifold biological activities including potent antibacterial and antifungal properties.[29] Fragment 2 was in principle able to inhibit the growth of the green algae but not to the same extent as the anachelin itself. At a very high concentration of $60 \mu \mathrm{M}$ fragment 2 reduced the growth of the green algae of about $17 \%$ (Figure 5A). Virtually the same inhibition effect was observed with anachelin (1) already at high nanomolar concentrations that is two orders of magnitude lower. Several quaternary ammonium compounds have been found to negatively effect the growth of green algae such as Scenedesmus intermedius, Dictyosphaerium chlorelloides, and Pseudokirchneriella subcapitata.[30] Thus, it is possible that the quaternary ammonium group of fragment 2 supported the total activity of anachelin, but to a minor extent. In contrast, fragment 3 did not have any negative impact on the growth of $K$. contorta, even at very high concentrations (Figure 5B). At two concentrations, a significant positive effect was observed, but the overall tendency was not different from the control. Comparing the fragments 2 and $\mathbf{3}$ one can speculate, that the impact of the quaternary ammonium, if bound to the tripeptide as in fragment 3 or in anachelin (1), is negligible for the overall growth inhibitory effect of anachelin.

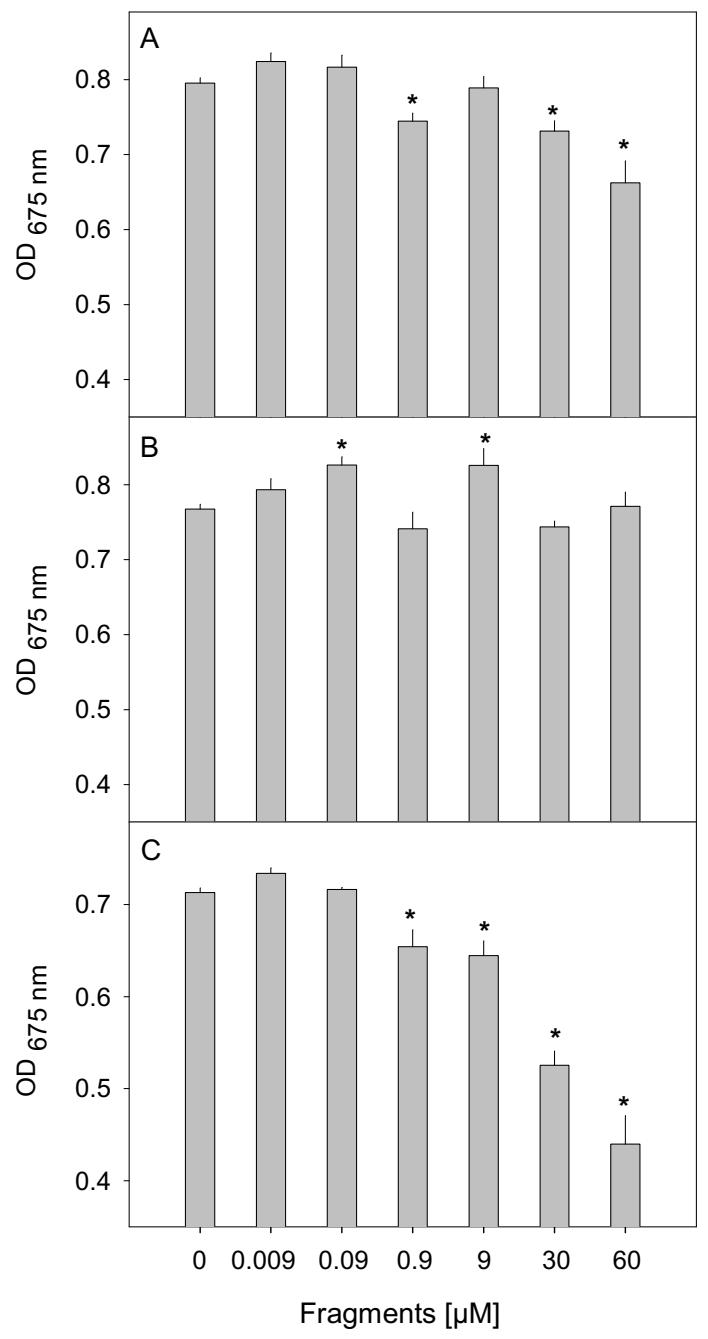

Figure 5. Growth of Kirchneriella contorta $310 \mathrm{~h}$ after addition of six different concentrations of different fragments. $K$. contorta was grown in $10 \mu \mathrm{M}$ Fe-citrate. Error bars indicate the standard deviation of three replicates. Asterisks above bar indicate that the concentration of the fragments significantly inhibited or promoted the growth of $K$. contorta ( $p<0.05$; tested by ANOVA, followed by Dunnett's post hoc tests). (A) Addition of fragment (2); (B) Addition of fragment (3); (C) Addition of fragment (4). 
Cyanobacteria are well recognized for the production of polyketides with broad biological activities.[31] In a next experiment, the polyketide fragment $\mathbf{4}$ of anachelin as prepared through the organocatalyic route above, was tested for the growth inhibitory effect on $K$. contorta. The polyketide inhibited the growth of the green algae in a dose-dependant manner, starting at nanomolar concentrations (Figure 5C). A significant impact could be observed at low micromolar concentrations. At $60 \mu \mathrm{M}$ a growth reduction of $38 \%$ was observed. Thus, the impact of fragment 4 on the growth of the green algae resembled the one of anachelin (1). It can be concluded that virtually the complete antialgal activity was retained in the polyketide fragment 4 (Figure 5).

Effect of Diastereoisomers on Growth of Kirchneriella contorta: We next investigated whether this inhibitory and allelopathic activity is unrelated to iron binding. Therefore, two diastereoisomers of anachelin, i.e. compounds $\mathbf{5}$ and 6 were evaluated, that are still able to bind iron, but differ in the configuration of the polyketide fragment. Interestingly, both the 3,5epi-anachelin (5) and the 3,5,6-epi-anachelin (6) were hardly affecting the growth of $K$. contorta (Figure 6). Only the 3,5-epi-anachelin showed a growth reduction of $12 \%$ at high $(60 \mu \mathrm{M})$ concentrations. Additionally, using 3,5,6-epianachelin, the molecule in which the configuration of all three hydroxy groups of the polyketide was inverted, no significant growth inhibition could be observed. This demonstrates that the relative configuration in the polyketide fragment of anachelin is crucial for allelopathic activity and that the observed growth inhibitory activity is unrelated to iron binding and siderophore activity.

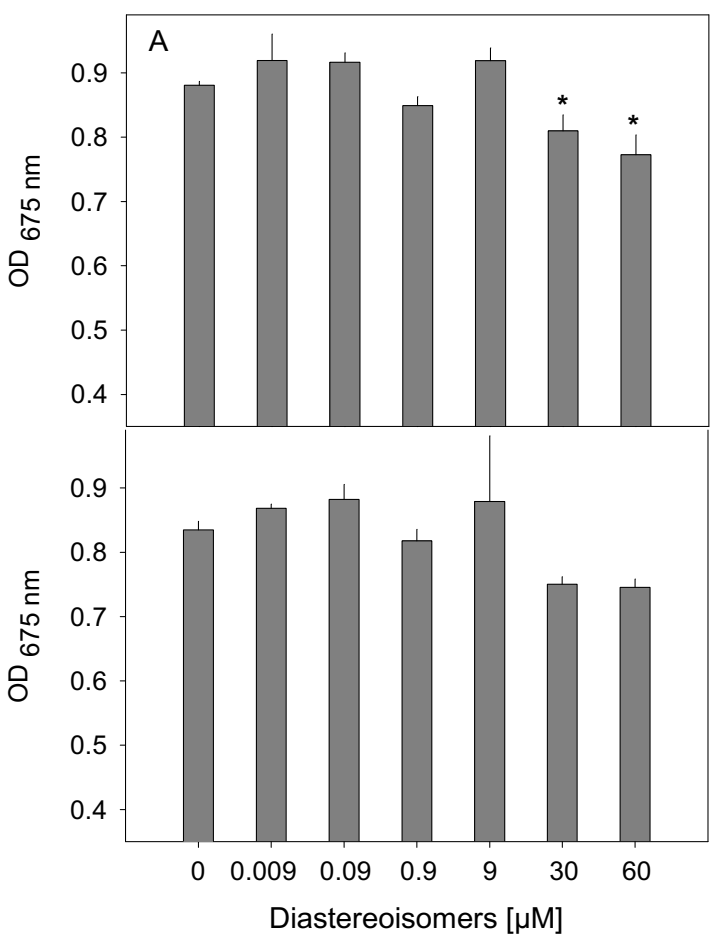

Figure 6. Growth of Kirchneriella contorta $310 \mathrm{~h}$ after addition of six different concentrations of the diastereoisomers. $K$. contorta was grown in $10 \mu \mathrm{M} \mathrm{Fe}-$ citrate. Error bars indicate the standard deviation of three replicates. Asterisks above bar indicate that the concentration of the diastereoisomers significantly inhibited the growth of $K$. contorta $(p<0.05$; tested by ANOVA, followed by Dunnett's post hoc tests). (A) Addition of 3,5-epi-anachelin (5). (B) Addition of 3,5,6epi-anachelin (6).

The Dual Mode of Action: All these results provide strong evidence on a molecular level that the siderophore anachelin possesses a dual mode of action both promoting the growth of cyanobacteria and concomitantly inhibiting the growth of competing phytoplankton. The two bioactivities are promoted by different fragments of the same molecule: whereas the tetrahydroquinolinium fragment (shown in green in 1) binds iron[18] and is thus mainly considered responsible for growth promotion, the polyketide fragment (shown in red in $\mathbf{1}$ ) is responsible for the allelopathic growth inhibition. It is interesting to note that the different bioactivities reside in 
fragments that might have different biosynthetic origins: The iron binding in the alkaloid part and the allelopathic activity in the polyketide fragment. As anachelin can be considered a product of mixed polyketide synthase and non-ribosomal peptide synthetase pathways, it can be speculated that these fragments, and thus the corresponding activities, have biosynthetically merged over time in one single compound. These experimental findings for a cyanobacterium are complemented by dual mode of action hybrids (sideromycins) isolated from bacteria, where both iron chelating and antibiotic fragments are complementary present.[32] In addition, anachelin (1) provides an interesting example of natural product with two different fragments merged. While many natural products can be structurally simplified,[33] in this case, one biological property would be lost. Based on structural considerations, such combined fragments having different functions could be operative in other natural products from cyanobacteria, such as the cyanopeptolins or the aeruginosins.[34]

Possible Role of Anachelin in the Environment: In the ecological context, it should be pointed out that the producer of anachelin, Anabaena cylindrica, is a filamentous freshwater cyanobacterium that can form biofilms and can occur also as planktonic organism in ponds and small lakes. In such densely populated environments, where cooperative behavior may be successful, secreted iron chelators are likely to be taken up by other cells of the filament or by other filaments thus increasing the overall amount of bioavailable iron. At the same time, the anachelin that is lost by diffusion can be predicted to display a secondary benefit by inhibiting the growth of competing organisms like eukaryotic algae. By using one secondary metabolite, Anabaena cylindrica can address two main challenges related to phytoplankton growth, i.e. nutrient limitation and inhibition of competitors.

\section{Conclusions}

In conclusion, we have shown that the iron chelator anachelin (1) stimulates growth of Microcystis aeruginosa while at the same time reducing the growth of two competing green algae, i.e. Kirchneriella and Chlamydomonas. Chemical synthesis of the derivatives such as 2-4 and diastereoisomers such as $\mathbf{5}$ and $\mathbf{6}$ allowed for the identification of the crucial fragment for this activity, where the polyketide moiety was shown to be responsible for allelopathy. Anachelin (1) can thus be considered a molecular hybrid with a dual mode of action. These experiments described herein provide therefore detailed experimental evidence for theories documented over the last 50 years regarding the role of iron chelators related to algal blooms.[1114]

The data presented in this study provide a strong rationale on a molecular level for the hypothesis that the excretion of iron chelators such as anachelin constitutes a strategy of cyanobacteria to dominate competing species.

\section{Author Contribution Statement}

\section{J. F. B. and K. G. conceived this work; J. F. B.} and K. G. designed the experiments; S. D. S., J. F. B., and Y. B. conducted the experiments; S. D. S., J. F. B., Y. B., F. J., and K. G. discussed the results and commented on the manuscript, S. D. S., J. F. B., and K. G. wrote the manuscript.

\section{Experimental Part}

\footnotetext{
Abbreviations. Boc = tert-butoxycarbonyl; $\mathrm{CDI}=$ carbonyldiimidazole; DMAP $=\mathrm{N}, \quad \mathrm{N}-$ dimethylaminopyridine; $\quad \mathrm{EDC}=\operatorname{ethyl}-(N, \quad N-$ dimethylaminopropyl)car-bodiimide; ether refers to diethylether; $\mathrm{FC}=$ flash chromatography; $\mathrm{HOBt}=1$ hydroxybenzotriazole; NMM = N-methyl-morpholine; $\mathrm{RT}$ = room temperature; TBS = tert-butyl-dimethylsilyl; $\mathrm{TFA}=$ trifluoroacetic acid; THF = tetrahydrofuran; $\mathrm{THQ}$ = 3-amino-6,7-dihydroxy-1,1-dimethyl-1,2,3,4tetrahydro-quinolinium; $Z$ = benzyloxycarbonyl.
} 
Unless otherwise stated, chemicals were purchased from Sigma-Aldrich, ABCR, Acros or Lancaster and used without further purification. Solvents for work-up and chromatography were distilled from technical quality. Solvents used for chemical transformations were either puriss quality or dried by filtration through activated aluminium oxide under argon or nitrogen $\left(\mathrm{H}_{2} \mathrm{O}\right.$ content $<10 \mathrm{ppm}$, Karl-Fischer titration). Reactions involving air or moisture sensitive reagents or intermediates were performed under argon or nitrogen in glassware which had been oven dried or dried by a heat gun under high vacuum. Concentration under reduced pressure was performed by rotary evaporation at $40{ }^{\circ} \mathrm{C}$ (unless otherwise specified). Yields refer to purified, dried and spectroscopically pure compounds. Analytical thin layer chromatography (TLC) was performed on Merck silica gel 60 F254 plates $(0.25 \mathrm{~mm}$ thickness) pre-coated with fluorescent indicator. The developed plates were examined under UV light and stained with ceric ammonium molybdate followed by heating. Flash chromatography was performed using silica gel 60 (230-240 mesh) from Fluka using a forced flow eluant at 0.3-0.5 bar pressure. ${ }^{1} \mathrm{H}-\mathrm{NMR}$ spectra were recorded on Varian Gemini Bruker DPX $400 \mathrm{MHz}$ or Bruker DRX $600 \mathrm{MHz}$ spectrometers at $298 \mathrm{~K}$ or $348 \mathrm{~K}$ in the indicated deuterated solvent, unless otherwise stated. Data are reported as follow: chemical shift $(\delta, p p m)$, multiplicity (s, singulet; d, doublet; t, triplet; q, quartet; m, multiplet or not resolved signal; br, broad signal; $p$, pseudo signal), coupling constant $(J, \mathrm{~Hz})$, integration. All signals were referenced to the internal solvent signal as standard $\left(\mathrm{CDCl}_{3}, \delta 7.26\right)$ or (DMSO-d $\left.\mathrm{d}_{6}, \delta 2.50\right)$ or (methanol- $\left.\mathrm{d}_{4}, \delta 3.31\right) .{ }^{13} \mathrm{C}-\mathrm{NMR}$ spectra were recorded with ${ }^{1} \mathrm{H}$-decoupling on Varian Gemini $100 \mathrm{MHz}$ or Bruker DPX $125 \mathrm{MHz}$ spectrometers at $298 \mathrm{~K}$ or $348 \mathrm{~K}$ in the indicated deuterated solvent, unless otherwise stated. All signals were referenced to the internal solvent signal as standard $\left(\mathrm{CDCl}_{3}, \delta 77.0\right)$ or (DMSO$d_{6}, \delta 39.52$ ) or (methanol- $\left.d_{4}, \delta 49.00\right)$. IR spectra were recorded using a Varian 800 FT-IR ATR Spectrometer. The, absorptions are reported in $\mathrm{cm}^{-1}$. Optical rotations [a] $D$ were measured at the sodium $D$ line using a $1 \mathrm{~mL}$ cell with a $1 \mathrm{dm}$ path length on a Jasco P-2000 digital polarimeter. The concentration $\mathrm{c}$ is given in $\mathrm{g} / 100 \mathrm{~mL}$ and the used solvent is $\mathrm{CHCl}_{3}$. All mass spectra (HRMS-ESI) were recorded by the Mass spectrometric Service of University of Bern on Sciex QSTAR Pulsar mass spectrometer using electrospray ionization. Compounds $\mathbf{1}$ and $\mathbf{2}$ were prepared according to literature procedure.[18,19]

Preparation of compound 3: Boc-L-Thr(OBn)-DSer(OBn)-L-Ser(OBn)-(3S)-THQ(OBn) chloride[20] (15 $\mathrm{mg}, 14.5 \mu \mathrm{mol})$ was dissolved in $\mathrm{MeOH}(150 \mu \mathrm{L})$ and glacial acetic acid $(30 \mu \mathrm{L})$ was added. The reaction vessel was flushed three times with argon and $\mathrm{Pd} / \mathrm{C}$ $(10 \%)$ was added. The reaction vessel was flushed with hydrogen three times and the reaction mixture stirred at room temperature for four hours. The reaction mixture was then filtered over celite and the solvent evaporated under reduced pressure. The residual acid was coevaporated wwith $_{\text {chloroform to give }}$ target compound 3 (quant). [ $\alpha$ ] $D=-310.8$ ( $\mathrm{C}=0.48$ in $\mathrm{H}_{2} \mathrm{O}$ ). FTIR (neat): $\mathrm{v}=3282,2976,2484,1657,1525$ $\mathrm{cm}^{-1}$. ${ }^{1} \mathrm{H}-\mathrm{NMR}\left(\mathrm{D}_{2} \mathrm{O}, 300 \mathrm{MHz}\right)$ 1.17-1.24 (m, 3H), 1.35 (s, 6H), 1.41 (s, 3H), 1.95 (s, residual acetic acid), 2.9$3.07(\mathrm{~m}, 1 \mathrm{H}), 2.07-3.2(\mathrm{~m}, 1 \mathrm{H}), 3.57(\mathrm{~m}, 7 \mathrm{H}), 3.89(\mathrm{~m}$, $4 \mathrm{H}), 4.04-4.24(\mathrm{~m}, 2 \mathrm{H}), 4.38-4.52(\mathrm{~m}, 2 \mathrm{H}), 4.56-4.7(\mathrm{~m}$, $1 \mathrm{H}), 6.8(\mathrm{~s}, 1 \mathrm{H}), 7.23(\mathrm{~s}, 1 \mathrm{H})$. HRMS calcd. for $\mathrm{C}_{26} \mathrm{H}_{42} \mathrm{~N}_{5} \mathrm{O}_{10}(\mathrm{M})^{+}:$584.2926, found: 584.2916.

\section{Preparation of compound 4:}

(S)-tert-Butyl 4-((S)-1-hydroxybut-3-en-1-yl)-2,2dimethyloxazolidine-3-carboxylate (8) was prepared by the addition of Garner aldehyde[20] (7) into $(R, R)$ Duthaler-Hafner reagent and allyl magnesium chloride complex following the literature procedure.[21a] The resulting alcohol was protected to afford the known (S)-tert-butyl 4-((S)-1-((tert-butyldimethylsilyl)oxy)but-3en-1-yl)-2,2-dimethyloxazolidine-3-carboxylate (9) and the spectra matched those reported.[21b]

\section{(S)-tert-butyl 4-((S)-3E-1-((tert- butyldimethylsilyl)oxy)-5-oxopent-3-en-1-yl)-2,2- dimethyloxazolidine-3-carboxylate Crotonaldehyde $(0.64 \mathrm{~mL}, 7.86 \mathrm{mmol}, 6.0 \mathrm{eq})$ was added to a stirred solution of (S)-tert-butyl 4-((S)-1((tert-butyldimethylsilyl)oxy)but-3-en-1-yl)-2,2dimethyloxazolidine-3-carboxylate (9) $(505 \mathrm{mg}, 1.31$ $\mathrm{mmol}, 1.0 \mathrm{eq})$ and Grubbs-Hoveyda $2^{\text {nd }}$ Generation Catalyst (16.4 mg, $26.2 \mu \mathrm{mol}, 0.02 \mathrm{eq}$ ) in DCM (15 mL). The resulting mixture was heated to reflux for $18 \mathrm{~h}$ and then cooled to room temperature. The solvent was removed in vacuo and the residue was purified by flash chromatography $\left(\mathrm{SiO}_{2}, 15: 1\right.$ pentane:EtOAc) to yield 10 as colourless oil (511 mg, 1.24 $\mathrm{mmol}, 94 \%)$. TLC:

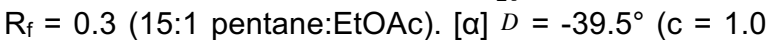
in $\mathrm{CHCl}_{3}$ ). FTIR (neat): $v=2931,1695,1366,1253$, 1170, 1074, 836, $776 \mathrm{~cm}^{-1}$. ${ }^{1} \mathrm{H}$ NMR $(600 \mathrm{MHz}$, DMSO, $348 \mathrm{~K}$ ) $\delta=9.60$ (d, $J=7.7 \mathrm{~Hz}, 1 \mathrm{H}$ ), 7.04 (ddd, $J=15.4$, 8.0, $6.6 \mathrm{~Hz}, 1 \mathrm{H}), 6.21(\mathrm{dd}, J=15.6,7.7 \mathrm{~Hz}, 1 \mathrm{H}), 4.42-$ $4.38(\mathrm{~m}, 1 \mathrm{H}), 4.18-4.14(\mathrm{~m}, 1 \mathrm{H}), 4.06-4.02(\mathrm{~m}, 2 \mathrm{H})$, $2.64-2.59(\mathrm{~m}, 1 \mathrm{H}), 2.53-2.46(\mathrm{~m}, 1 \mathrm{H}), 1.63(\mathrm{~s}, 3 \mathrm{H})$, $1.56(\mathrm{~s}, 9 \mathrm{H}), 1.52(\mathrm{~s}, 3 \mathrm{H}), 0.96(\mathrm{~s}, 9 \mathrm{H}), 0.18(\mathrm{~s}, 3 \mathrm{H})$, $0.14(\mathrm{~s}, 3 \mathrm{H}) .{ }^{13} \mathrm{C}$ NMR $(151 \mathrm{MHz}$, DMSO, 348K) $\delta=$ 192.8, 155.3, 151.4, 134.0, 93.7, 79.2, 69.5, 62.0, 59.6, $34.0,27.7,25.7,25.1,22.5,17.1,-5.0,-5.2$. HRMS (ESI+) $\mathrm{m} / \mathrm{z}$ calc'd for $\mathrm{C}_{21} \mathrm{H}_{40} \mathrm{O}_{5} \mathrm{NSi}[\mathrm{M}+\mathrm{H}]^{+}:$414.2670, found 414.2666. 
(S)-tert-butyl butyldimethylsilyl)oxy)-3-hydroxy-5-methoxy-5oxopentyl)-2,2-dimethyloxazolidine-3-carboxylate

(11): $\mathrm{H}_{2} \mathrm{O}_{2}$ (35\% aq., $\left.78 \mathrm{~mL}, 0.96 \mathrm{mmol}, 1.2 \mathrm{eq}\right)$ was added to stirred solution of 10 (331 $\mathrm{mg}, 0.80 \mathrm{mmol}, 1.0$ eq) and (S)-(-)- $\alpha, \alpha$-diphenyl-2-pyrrolidinemethanol trimethylsilyl ether $(27.4 \mathrm{mg}, 0.08 \mathrm{mmol}, 0.1 \mathrm{eq})$ in $\operatorname{DCM}(4 \mathrm{~mL})$ at room temperature under argon atmosphere. Stirring was continued at room temperature for $16 \mathrm{~h}$ and then the solvent was removed. The crude mixture was further dried under high vacuum ( $2 \mathrm{~h}$, room temperature), the diastereoselectivity of the crude epoxy aldehyde was measured by ${ }^{1} \mathrm{H} N M R$, and the residue was then dissolved in DCM $(4 \mathrm{~mL})$. To the reaction mixture were then sequentially added 6,7-dihydro-2pentafluorophenyl-5H-pyrrolo[2,1-c]-1,2,4-triazolium tetrafluoroborate $(14.4 \mathrm{mg}, 0.04 \mathrm{mmol}, 0.05 \mathrm{eq})$, methanol ( $162 \mu \mathrm{L}, 4.0 \mathrm{mmol}, 5.0 \mathrm{eq})$ and triethylamine (68 $\mu \mathrm{L}, 0.4 \mathrm{mmol}, 0.5 \mathrm{eq}$ ). Stirring was continued for $12 \mathrm{~h}$ at room temperature. The solvent was removed in vacuo and the residue was purified by flash chromatography $\left(\mathrm{SiO}_{2}, 6: 1\right.$ pentane:EtOAc) to yield the target compound 11 (inseparable mixture of diastereomers) as colourless oil (298 mg, $0.64 \mathrm{mmol}$, $81 \%)$. TLC: $R_{f}=0.3$ (6:1 pentane:EtOAc). For mixture of diastereomers and rotamers: ${ }^{1} \mathrm{H}$ NMR $(400 \mathrm{MHz}$, $\left.\mathrm{CDCl}_{3}, 298 \mathrm{~K}\right) \delta=4.43-4.26(\mathrm{~m}, 1 \mathrm{H}), 4.23-4.06(\mathrm{~m}$ $2 \mathrm{H}), 4.00-3.80(\mathrm{~m}, 2 \mathrm{H}), 3.78-3.54(\mathrm{~m}, 3 \mathrm{H}), 3.43-$ $3.17(\mathrm{~m}, 1 \mathrm{H}), 2.59-2.35(\mathrm{~m}, 2 \mathrm{H}), 1.71-1.62(\mathrm{~m}, 2 \mathrm{H})$, $1.59-1.36(\mathrm{~m}, 15 \mathrm{H}), 0.95-0.79(\mathrm{~m}, 9 \mathrm{H}), 0.23-0.03$ $(\mathrm{m}, 6 \mathrm{H}) .{ }^{13} \mathrm{C}$ NMR $\left(101 \mathrm{MHz}, \mathrm{CDCl}_{3}, 298 \mathrm{~K}\right) \delta=172.3$, 152.7 and $152.1,95.0$ and $94.3,80.3,70.6$ and 70.1 , $67.5,63.1$ and $62.8,60.4$ and 59.7, 51.6, 41.6 and $41.3,37.0,28.6$ and $28.4,26.5$ and $25.9,25.7$ and 25.7, 23.9 and $22.4,17.9$ and $17.7,-3.8$ and -4.1 and 4.9 and -5.3 . HRMS (ESI+) m/z calc'd for $\mathrm{C}_{22} \mathrm{H}_{44} \mathrm{O}_{7} \mathrm{NSi}$ $[\mathrm{M}+\mathrm{H}]^{+}:$462.2882, found 462.2876 .

(S)-tert-butyl 4-((5S,7R)-7-(2-methoxy-2-oxoethyl)2,2,3,3,9,9,10,10-octamethyl-4,8-dioxa-3,9disilaundecan-5-yl)-2,2-dimethyloxazolidine-3carboxylate (12): Lutidine (104 $\mu \mathrm{L}, 0.88 \mathrm{mmol}, 2.0 \mathrm{eq})$ and TBSOTf (152 $\mu \mathrm{L}, 0.66 \mathrm{mmol}, 1.5 \mathrm{eq})$ were successively added to a solution of 11 (203 $\mathrm{mg}, 0.44$ mmol, $1.0 \mathrm{eq})$ in DCM $(2 \mathrm{~mL})$ at $-20{ }^{\circ} \mathrm{C}$. The mixture was stirred at $-20{ }^{\circ} \mathrm{C}$ for $1 \mathrm{~h}$ and then slowly warm to room temperature over $1 \mathrm{~h}$. Then $\mathrm{CH}_{2} \mathrm{Cl}_{2}$ was added and the organic phase was washed $3 \times$ with citric acid $(10 \%)$ and $2 \times$ with $\mathrm{H}_{2} \mathrm{O}$, dried over $\mathrm{Na}_{2} \mathrm{SO}_{4}$ and filtered. The solvent was removed in vacuo and the residue was purified by flash chromatography $\left(\mathrm{SiO}_{2}, 50: 1\right.$ to 30:1 pentane:EtOAc) to yield 12 as colourless oil (12 as major diastereomer $209 \mathrm{mg}$ and 12' as minor diastereomer $35 \mathrm{mg}, 0.42 \mathrm{mmol}$ overall, $96 \%$ overall yieldf). For 12: TLC: $R_{f}=0.30$ (30:1 pentane:EtOAc). [a] $D=-55.3^{\circ}$ (c = 1.0 in $\mathrm{CHCl}_{3}$ ). FTIR (neat): $\mathrm{v}=2955$, 2931, 1743, 1705, 1473, 1384, 1255, 1170, 837, 777 $\mathrm{cm}^{-1}$. ${ }^{1} \mathrm{H}$ NMR $\left(600 \mathrm{MHz}, \mathrm{DMSO}-\mathrm{d}_{6}, 348 \mathrm{~K}\right) \delta=4.31-$ $4.24(\mathrm{~m}, 1 \mathrm{H}), 4.19-4.07(\mathrm{~m}, 1 \mathrm{H}), 4.02-3.96(\mathrm{~m}, 1 \mathrm{H})$, $3.95-3.91(\mathrm{~m}, 1 \mathrm{H}), 3.91-3.86(\mathrm{~m}, 1 \mathrm{H}), 3.59(\mathrm{~s}, 3 \mathrm{H})$, $2.50-2.46(\mathrm{~m}, 1 \mathrm{H}), 2.25(\mathrm{dd}, J=14.5,8.5 \mathrm{~Hz}, 1 \mathrm{H})$, $1.70-1.60(\mathrm{~m}, 2 \mathrm{H}), 1.52(\mathrm{~s}, 3 \mathrm{H}), 1.45(\mathrm{~s}, 9 \mathrm{H}), 1.41(\mathrm{~s}$, $3 \mathrm{H}), 0.89(\mathrm{~s}, 9 \mathrm{H}), 0.85(\mathrm{~s}, 9 \mathrm{H}), 0.11(\mathrm{~s}, 6 \mathrm{H}), 0.05(\mathrm{~s}$, $3 \mathrm{H}), 0.01$ (s, 3H). ${ }^{13} \mathrm{C}$ NMR (151 MHz, DMSO-d 6 , $348 \mathrm{~K}) \delta=170.6,151.3,93.6,79.2,67.1,66.6,62.0$, $59.3,50.5,40.9,38.1,27.7,25.5,25.2,25.2,22.6$, $17.1,17.1,-4.5,-4.7,-5.3,-5.4$. HRMS (ESI+) m/z calc'd for $\mathrm{C}_{28} \mathrm{H}_{58} \mathrm{O}_{7} \mathrm{NSi}_{2}[\mathrm{M}+\mathrm{H}]^{+}: \quad 576.3746$, found 576.3741.

For minor diastereomer 12': TLC: $R_{f}=0.33$ (30:1 pentane:EtOAc); [a] $D=-15.9^{\circ}$ (c = 0.5 in $\mathrm{CHCl}_{3}$ ). FTIR (neat): $v=2955,2931,1743,1705,1473,1384$, $1255,1170,837,777 \mathrm{~cm}^{-1}$. ${ }^{1} \mathrm{H}$ NMR $(600 \mathrm{MHz}$, DMSO$\left.\mathrm{d}_{6}, 348 \mathrm{~K}\right) \delta=4.29-4.22(\mathrm{~m}, 1 \mathrm{H}), 4.21-4.15(\mathrm{~m}, 1 \mathrm{H})$, $3.98-3.93(\mathrm{~m}, 1 \mathrm{H}), 3.93-3.87(\mathrm{~m}, 2 \mathrm{H}), 3.59(\mathrm{~s}, 3 \mathrm{H})$, 2.58 (dd, $J=14.9,4.6 \mathrm{~Hz}, 1 \mathrm{H}$ ), 2.45 (dd, $J=14.9,7.3$ $\mathrm{Hz}, 1 \mathrm{H}$ ), 1.70 (ddd, $J=14.3,5.9,2.1 \mathrm{~Hz}, 1 \mathrm{H}), 1.59-$ $1.54(\mathrm{~m}, 1 \mathrm{H}), 1.53(\mathrm{~s}, 3 \mathrm{H}), 1.45(\mathrm{~s}, 9 \mathrm{H}), 1.41(\mathrm{~s}, 3 \mathrm{H})$, $0.88(\mathrm{~s}, 9 \mathrm{H}), 0.84(\mathrm{~s}, 9 \mathrm{H}), 0.12(\mathrm{~s}, 6 \mathrm{H}), 0.06(\mathrm{~s}, 3 \mathrm{H})$, $0.03(\mathrm{~s}, 3 \mathrm{H}) .{ }^{13} \mathrm{C}$ NMR $(151 \mathrm{MHz}$, DMSO-d 6 , 348K) $\delta=$ $170.4,151.5,93.5,79.1,68.3,67.6,61.8,59.7,50.4$, 43.4, 38.6, 27.7, 25.7, 25.2, 25.2, 22.4, 17.1, 17.1, -4.4, $-4.6,-4.8,-5.1$. HRMS (ESI+) $\mathrm{m} / \mathrm{z}$ calc'd for $\mathrm{C}_{28} \mathrm{H}_{58} \mathrm{O}_{7} \mathrm{NSi}_{2}[\mathrm{M}+\mathrm{H}]^{+}: 576.3746$, found 576.3749 .

(3R,5S,6S)-methyl 6-(2-(benzyloxy)benzamido)-3,5bis((tert-butyldimethylsilyl)oxy)-7-

hydroxyheptanoate (13): TFA $(0.4 \mathrm{~mL})$ was added drop-wise to a solution of $12(118 \mathrm{mg}, 0.20 \mathrm{mmol}, 1.0$ eq) in DCM $(2.0 \mathrm{~mL})$ at $0{ }^{\circ} \mathrm{C}$. The mixture was stirred at $0{ }^{\circ} \mathrm{C}$ for $1 \mathrm{~h}$ and then solvent was removed under reduced pressure keeping the temperature below $5{ }^{\circ} \mathrm{C}$. Excess TFA was removed using high vacuum $(3 \mathrm{~h})$ at room temperature. The crude material 13' was dissolved in dry DCM $(1.0 \mathrm{~mL})$ and used for next step without further purification.

EDC. $\mathrm{HCl}(47 \mathrm{mg}, 0.24 \mathrm{mmol}, 1.2 \mathrm{eq})$, HOBt (33 mg, $0.24 \mathrm{mmol}, 1.2 \mathrm{eq})$ and NMM $(68 \mu \mathrm{L}, 0.60 \mathrm{mmol}, 3.0$ eq) were successively added to a solution of O-Bnsalicylic acid (60 mg, $0.24 \mathrm{mmol}, 1.2 \mathrm{eq}$ ) in DCM (1.0 $\mathrm{mL}$ ) at room temperature. The mixture was stirred at room temperature for 30 mins and then a solution of $13^{\prime}$ in DCM $(1.0 \mathrm{~mL})$ was added. Stirring was continued for $20 \mathrm{~h}$. The solvent was removed in vacuo and the residue was purified by flash chromatography $\left(\mathrm{SiO}_{2}, 4: 1\right.$ pentane:EtOAc) to yield 13 as colourless oil (99 $\mathrm{mg}, \quad 0.15 \mathrm{mmol}, 75 \%)$. TLC: $\mathrm{R}_{\mathrm{f}}=0.2(4: 1$ 
pentane:EtOAc). [a] $D=+9.9^{\circ}$ (c $=1.0$ in $\mathrm{CHCl}_{3}$ ). FTIR (neat): $v=2954,2930,1729,1601,1487,1451,1295$, 1237, 1086, $887 \mathrm{~cm}^{-1}$. ${ }^{1} \mathrm{H}$ NMR $\left(400 \mathrm{MHz}_{2} \mathrm{CDCl}_{3}\right.$, $298 \mathrm{~K}) \delta=8.21(\mathrm{~d}, J=8.1 \mathrm{~Hz}, 1 \mathrm{H}), 8.18(\mathrm{dd}, J=7.8$, $1.8 \mathrm{~Hz}, 1 \mathrm{H}), 7.45-7.29(\mathrm{~m}, 6 \mathrm{H}), 7.05\left(\mathrm{p} \mathrm{t}, J_{1}=J_{2}=\right.$ $7.5 \mathrm{~Hz}, 1 \mathrm{H}), 6.96(\mathrm{~d}, J=8.3 \mathrm{~Hz}, 1 \mathrm{H}), 5.28(\mathrm{~s}, 2 \mathrm{H}), 4.39$ $-4.28(\mathrm{~m}, 1 \mathrm{H}), 4.21-4.07(\mathrm{~m}, 2 \mathrm{H}), 3.76-3.62(\mathrm{~m}$, 2H), 3.49 (s, 3H), 2.54 (br s, $1 \mathrm{H}), 2.40$ (d, J = 6.0 Hz, $2 \mathrm{H}), 1.78-1.61(\mathrm{~m}, 2 \mathrm{H}), 0.88(\mathrm{~s}, 9 \mathrm{H}), 0.83(\mathrm{~s}, 9 \mathrm{H})$ 0.11 (s, 3H), 0.09 (s, 3H), 0.08 (s, 3H), 0.07 (s, 3H) ${ }^{13} \mathrm{C}$ NMR $\left(101 \mathrm{MHz}, \mathrm{CDCl}_{3}, 298 \mathrm{~K}\right) \delta=171.2,166.4$, 156.6, 135.8, 132.8, 132.4, 128.8, 128.4, 127.2, 121.8, $121.4,113.1,70.9,68.9,66.2,64.5,54.0,51.3,43.1$, $41.5,25.8,25.7,17.8,17.8,-4.4,-4.5,-4.6,-4.8$ HRMS (ESI+) $\mathrm{m} / \mathrm{z}$ calc'd for $\mathrm{C}_{34} \mathrm{H}_{56} \mathrm{O}_{7} \mathrm{NSS}_{2}[\mathrm{M}+\mathrm{H}]^{+}$: 646.3590 , found 646.3580

\section{$(3 R, 5 S, 6 S)$-methy} butyldimethylsilyl)oxy)-7-hydroxy-6-(2hydroxybenzamido)heptanoate (4'): Compound 13 (34.5 mg, $53.4 \mu \mathrm{mol}, 1.0 \mathrm{eq}$ ) was dissolved in dry $\mathrm{CH}_{3} \mathrm{OH}(2.0 \mathrm{~mL})$, and glacial acetic acid $(200 \mu \mathrm{L})$ was added. The reaction flask was flushed three times with argon, and then $10 \% \mathrm{Pd} / \mathrm{C}(11.4 \mathrm{mg}, 10.7 \mu \mathrm{mol}, 0.2$ eq) was added. The reaction flask was flushed three times with $\mathrm{H}_{2}$, and the reaction mixture was stirred 2.5 $\mathrm{h}$ at room temperature. The reaction mixture was then filtered over celite and solvent was removed in vacuo to yield $4^{\prime}$ as colourless oil ( $29.5 \mathrm{mg}, 53_{2} 1 \mu \mathrm{mol}, 99 \%$ ). TLC: $\mathrm{R}_{\mathrm{f}}=0.5$ (4:1 pentane:EtOAc). [a] $D=-14.4^{\circ}$ (c $=$ 1.0 in $\mathrm{CHCl}_{3}$ ). FTIR (neat): $\mathrm{v}=3343,2930,2360,1740$ 1636, 1536, 1362, 1254, 1097, 1038, 835, $776 \mathrm{~cm}^{-1}$. ${ }^{1} \mathrm{H}$ NMR $\left(400 \mathrm{MHz}, \mathrm{CDCl}_{3}, 298 \mathrm{~K}\right) \delta=7.43-7.37(\mathrm{~m}$, $1 \mathrm{H}), 7.31(\mathrm{~d}, J=7.9 \mathrm{~Hz}, 1 \mathrm{H}), 6.98(\mathrm{~d}, J=8.3 \mathrm{~Hz}, 1 \mathrm{H})$, $6.93(\mathrm{~d}, J=8.2 \mathrm{~Hz}, 1 \mathrm{H}), 6.89-6.81(\mathrm{~m}, 1 \mathrm{H}), 4.28(\mathrm{dd}$ $J=13.5,6.5 \mathrm{~Hz}, 1 \mathrm{H}), 4.21(\mathrm{dd}, J=8.1,4.9 \mathrm{~Hz}, 1 \mathrm{H})$, $4.17-4.09(\mathrm{~m}, 1 \mathrm{H}), 3.80(\mathrm{dd}, J=10.5,6.6 \mathrm{~Hz}, 1 \mathrm{H})$, $3.74-3.64(\mathrm{~m}, 1 \mathrm{H}), 3.53(\mathrm{~s}, 3 \mathrm{H}), 2.50(\mathrm{dd}, J=14.7$, $5.0 \mathrm{~Hz}, 1 \mathrm{H}$ ), 2.43 (dd, $J=14.7,7.3 \mathrm{~Hz}, 1 \mathrm{H}$ ), 2.09 (br s, $1 \mathrm{H}), 1.82-1.68(\mathrm{~m}, 2 \mathrm{H}), 0.94(\mathrm{~s}, 9 \mathrm{H}), 0.88(\mathrm{~s}, 9 \mathrm{H})$, $0.15(\mathrm{~s}, 3 \mathrm{H}), 0.13(\mathrm{~s}, 3 \mathrm{H}), 0.11(\mathrm{~s}, 3 \mathrm{H}), 0.08(\mathrm{~s}, 3 \mathrm{H})$. ${ }^{13} \mathrm{C}$ NMR $\left(101 \mathrm{MHz}, \mathrm{CDCl}_{3}, 298 \mathrm{~K}\right) \delta=171.1,170.5$, $161.6,134.4,125.3,118.8,118.7,114.0,68.2,66.1$, 63.6, 52.9, 51.5, 43.0, 42.1, 25.9, 25.7, 17.9, 17.8, -4.2, $-4.5,-4.6, \quad-4.9$. HRMS (ESI+) $\mathrm{m} / \mathrm{z}$ calc'd for $\mathrm{C}_{27} \mathrm{H}_{50} \mathrm{O}_{7} \mathrm{NSi}_{2}[\mathrm{M}+\mathrm{H}]^{+}: 556.3120$, found 556.3111.

\section{(3R,5S,6S)-methy}

3,5,7-trihydroxy-6-(2hydroxybenzamido)heptanoate (4): A solution of $\mathrm{HCl}$ (4 M) in dioxane $(91 \mu \mathrm{L})$ was added drop-wise to a solution of $4^{\prime}(28.9 \mathrm{mg}, 52.0 \mu \mathrm{mol}, 1.0 \mathrm{eq})$ in dry methanol $(2.1 \mathrm{~mL})$ at $0{ }^{\circ} \mathrm{C}$. The mixture was stirred at $0{ }^{\circ} \mathrm{C}$ for $1.5 \mathrm{~h}$. All volatiles were removed under reduced pressure while keeping the solution temperature below $5{ }^{\circ} \mathrm{C}$. The residue was further dried using high vacuum $(1 \mathrm{~h})$ at room temperature to provide the desired product as colorless oil $(16.9 \mathrm{mg}$, 51. $2 \mathrm{fmol}, 99 \%)$. TLC: $\mathrm{R}_{\mathrm{f}}=0.3$ (10:1 DCM:methanol). [a] $D=-23.7^{\circ}$ (c=1.0 in $\mathrm{MeOH}$ ). FTIR (neat): $v=3350$, 2955, 2363, 1721, 1636, 1546, 1443, 1307, 1256, 757 $\mathrm{cm}^{-1}$. ${ }^{1} \mathrm{H}$ NMR $(400 \mathrm{MHz}, \mathrm{MeOD}, 298 \mathrm{~K}) \delta=7.87(\mathrm{dd}, \mathrm{J}$ $=8.1,1.4 \mathrm{~Hz}, 1 \mathrm{H}), 7.41-7.33(\mathrm{~m}, 1 \mathrm{H}), 6.95-6.88(\mathrm{~m}$, $2 \mathrm{H}), 4.32-4.23(\mathrm{~m}, 1 \mathrm{H}), 4.23-4.12(\mathrm{~m}, 2 \mathrm{H}), 3.79-$ $3.68(\mathrm{~m}, 2 \mathrm{H}), 3.62(\mathrm{~s}, 3 \mathrm{H}), 2.52(\mathrm{dd}, J=15.1,4.8 \mathrm{~Hz}$, $1 \mathrm{H}), 2.44(\mathrm{dd}, J=15.1,8.0 \mathrm{~Hz}, 1 \mathrm{H}), 1.78-1.63(\mathrm{~m}$, 2H). ${ }^{13} \mathrm{C}$ NMR (101 MHz, MeOD) $\delta=173.7,170.3$, 160.1, 134.6, 130.0, 120.3, 118.1, 117.9, 69.1, 67.7, 62.8, 55.8, 52.0, 43.2, 41.7. HRMS (ESI+) m/z calc'd for $\mathrm{C}_{15} \mathrm{H}_{23} \mathrm{O}_{7} \mathrm{~N}[\mathrm{M}+\mathrm{H}]^{+}:$329.1469, found 329.1456.

Preparation of 3,5-epi-anachelin (5): Boc-L$\operatorname{Thr}(\mathrm{OBn})-\mathrm{D}-\mathrm{Ser}(\mathrm{OBn})-\mathrm{L}-\mathrm{Ser}(\mathrm{OBn})-(3 \mathrm{~S})$ -

THQ(OBn)[18,20] (25 mg, $14.9 \mu \mathrm{mol})$ was dissolved in dioxane $(0.4 \mathrm{~mL})$ and $\mathrm{HCl}$-dioxane $(4 \mathrm{M}, 90 \mu \mathrm{mol})$ was added at $0{ }^{\circ} \mathrm{C}$. It was stirred one hour at this temperature and three hours at room temperature. The solvent was removed under reduced pressure and the product dried under high vacuum two hours. It was used without further purification.

To a solution of (6S)-6-(2-benzyloxy-benzoylamino)(3S,5R)-3,5,7-tris-(tert-butyl-dimethyl-silanyloxy)heptanoic acid[18,20] $(11 \mathrm{mg}, 14.9 \mu \mathrm{mol})$ in DMF $(0.4$ $\mathrm{mL})$ at $-18{ }^{\circ} \mathrm{C}$ was added iBuOCOCl $(1.9 \mu \mathrm{L}, 14.9$ $\mu \mathrm{mol})$ and NMM $(5.4 \mu \mathrm{L}, 49.2 \mu \mathrm{mol})$. The reaction mixture was stirred at this temperature for $20 \mathrm{~min}$. Then H-L-Thr(OBn)-D-Ser(OBn)-L-Ser(OBn)-(3S)$\mathrm{THQ}(\mathrm{OBn})(15 \mathrm{mg}, 14.9 \mu \mathrm{mol})$ dissolved in DMF $(0.4$ $\mathrm{mL})$ and NMM (3.3 $\mu \mathrm{L}, 29.8 \mu \mathrm{mol})$ was added dropwise at $-18{ }^{\circ} \mathrm{C}$ and it was allowed to warm over four hours. The solvent was evaporated under reduced pressure and the residue taken up in AcOEt. It was washed $3 x$ with $\mathrm{H}_{2} \mathrm{O}$, and the resulting water extracted $3 x$ with AcOEt. The combined organic phases were dried over $\mathrm{Na}_{2} \mathrm{SO}_{4}$, filtered and evaporated under reduced pressure. $\mathrm{FC}\left(\mathrm{CH}_{2} \mathrm{Cl}_{2} / \mathrm{MeOH}: 10 / 1\right)$ gave (3S,5R,6S)-6-(benzyloxy-benzoylamino)-3,5,7-tris-

(tert-butyl-dimethyl-silanoxy)-heptanoic acid-LThr(OBn)-D-Ser(OBn)-L-Ser(OBn)-(3S)-THQ(OBn) (9 $\mathrm{mg}, 5.4 \mu \mathrm{mol}, 36 \%)$ as colorless oil.

(3S,5R,6S)-6-(Benzyloxy-benzoylamino)-3,5,7-tris(tert-butyl-dimethyl-silanoxy)-heptanoic acid-L$\operatorname{Thr}(\mathrm{OBn})-\mathrm{D}-\mathrm{Ser}(\mathrm{OBn})-\mathrm{L}-\mathrm{Ser}(\mathrm{OBn})-(3 \mathrm{~S})-\mathrm{THQ}(\mathrm{OBn}) \quad$ (9 $\mathrm{mg}, 5.4 \mu \mathrm{mol})$ was dissolved in $\mathrm{CH}_{3} \mathrm{OH}(350 \mu \mathrm{L})$ and glacial acetic acid ( 30 drops) was added. The reaction vessel was flushed three times with $\mathrm{Ar}$, and then $\mathrm{Pd} / \mathrm{C}$ (10 \%, $7 \mathrm{mg}$ ) was added. The reaction vessel was three times flushed with $\mathrm{H}_{2}$ and the reaction mixture was stirred 2.5 hours at $\mathrm{RT}$. The reaction mixture was then filtered over celite and the solvent removed under reduced pressure. The residue was dissolved in cold 
$\mathrm{MeOH}$ containing $1 \% \mathrm{HCl}(1 \mathrm{~mL})$ and the solution stirred for four hours at $0^{\circ} \mathrm{C}$. Then the solvent was evaporated under reduced pressure and the residual acid was coevaporated three times with chloroform. It was dissolved in deuterated water and lyophilized to give 3,5-epi-anachelin (5) (2.3. $\mathrm{mg}, 2.9 \mu \mathrm{mol}, 55 \%)$ as light yellow fluffy powder. [a] $D=-60.0^{\circ}(\mathrm{C}=0.1$ in $\mathrm{H}_{2} \mathrm{O}$ ). FTIR (neat): $v=3679,1643,1609,1571,1537$ $\mathrm{cm}^{-1}$. HRMS calcd. for $\mathrm{C}_{35} \mathrm{H}_{51} \mathrm{~N}_{6} \mathrm{O}_{14}(\mathrm{M})^{+}:$779.3458, found: $779.3448 .{ }^{1} \mathrm{H}-\mathrm{NMR}$ data, see supporting information.

\section{Preparation of 3,5,6-epi-anachelin (6): Boc-L-} $\operatorname{Thr}(\mathrm{OBn})-\mathrm{D}-\mathrm{Ser}(\mathrm{OBn})-\mathrm{L}-\mathrm{Ser}(\mathrm{OBn})-(3 S)$ -

$\mathrm{THQ}(\mathrm{OBn})[18,20](38 \mathrm{mg}, 35.4 \mu \mathrm{mol})$ was dissolved in dioxane $(0.6 \mathrm{~mL})$ and $\mathrm{HCl} \cdot$ dioxane $(4 \mathrm{M}, 100 \mu \mathrm{mol})$ was added at $0{ }^{\circ} \mathrm{C}$. It was stirred 1 hour at this temperature and 3 hours at RT. The solvent was removed under reduced pressure and the product dried under high vacuum 2 hours. It was used without further purification. To a solution of (6R)-6-(2benzyloxy-benzoylamino)-(3S,5R)-3,5,7-tris-(tert-butyldimethyl-silanyloxy)-heptanoic acid[18,20] (24 mg, $32.2 \mu \mathrm{mol})$ in DMF $(0.6 \mathrm{~mL})$ at $-18{ }^{\circ} \mathrm{C}$ was added iBuOCOCl $(4.2 \mu \mathrm{L}, 32.2 \mu \mathrm{mol})$ and NMM $(13 \mu \mathrm{L}, 113$ $\mu \mathrm{mol})$. The reaction mixture was stirred at this temperature for $20 \mathrm{~min}$. Then H-L-Thr(OBn)-DSer(OBn)-L-Ser(OBn)-(3S)-THQ(OBn) (36 mg, 35.4 $\mu \mathrm{mol})$ dissolved in DMF $(0.5 \mathrm{~mL})$ and NMM $(7 \mu \mathrm{L}, 38$ $\mu \mathrm{mol})$ was added dropwise at $-18{ }^{\circ} \mathrm{C}$ and it was allowed to warm over four hours. The solvent was evaporated under reduced pressure and the residue taken up in AcOEt. It was washed three times with $\mathrm{H}_{2} \mathrm{O}$, and the resulting water extracted three times with AcOEt. The combined organic phases were dried over $\mathrm{Na}_{2} \mathrm{SO}_{4}$, filtered and evaporated under reduced pressure. $\mathrm{FC}\left(\mathrm{CH}_{2} \mathrm{Cl}_{2} / \mathrm{MeOH}: 10 / 1\right)$ gave (3S,5R,6R)-6-(benzyloxy-benzoylamino)-3,5,7-tris-

(tert-butyl-dimethyl-silanoxy)-heptanoic acid-L$\operatorname{Thr}(\mathrm{OBn})-\mathrm{D}-\mathrm{Ser}(\mathrm{OBn})-\mathrm{L}-\mathrm{Ser}(\mathrm{OBn})-(3 S)-\mathrm{THQ}(\mathrm{OBn})$ (27 $\mathrm{mg}, 16 \mu \mathrm{mol}, 50 \%$ ) as colorless oil.

This compound (9 mg, $5.3 \mu \mathrm{mol})$ was dissolved in $\mathrm{CH}_{3} \mathrm{OH}(350 \mu \mathrm{L})$ and glacial acetic acid (30 drops) was added. The reaction vessel was flushed three times with $\mathrm{Ar}$, and then $\mathrm{Pd} / \mathrm{C}(10 \%, 7 \mathrm{mg})$ was added. The reaction vessel was three times flushed with $\mathrm{H}_{2}$ and the reaction mixture was stirred 2.5 hours at RT. The reaction mixture was then filtered over celite and the solvent removed under reduced pressure. The residue was dissolved in cold $\mathrm{MeOH}$ containing $1 \% \mathrm{HCl}(1 \mathrm{~mL})$ and the solution stirred for 4 hours at $0{ }^{\circ} \mathrm{C}$. Then the solvent was evaporated under reduced pressure and the residual acid was co-evaporated three times with chloroform. It was dissolved in deuterated water and lyophilized to give 3,5,6-epi-anachelin (6) $(2.1 \mathrm{mg}, 2.6$ $\mu \mathrm{mol}, 50 \%)$ as light yellow fluffy powder. [a] $D=-26.7^{\circ}$ ( $\mathrm{C}=0.12$ in $\mathrm{H}_{2} \mathrm{O}$ ). FTIR (neat): $\mathrm{v}=3679,1638,1530$ $\mathrm{cm}^{-1}$. HRMS calcd. for $\mathrm{C}_{35} \mathrm{H}_{51} \mathrm{~N}_{6} \mathrm{O}_{14}(\mathrm{M})^{+}:$779.3458, found: 779.3447. ${ }^{1} \mathrm{H}-\mathrm{NMR}$ data see supporting information.

Biological assays. The blue-green-colored unicellular cyanobacterium Microcystis aeruginosa PCC 7806 was provided by R. Rippka (Pasteur Culture Collection, Paris, France); the unicellular green alga Kirchneriella contorta SAG 11.81 was provided by the Culture Collection of Algae at the University of Göttingen, Germany. Both strains were grown in Erlenmeyer flasks on a cyanobacterial medium as described by Jüttner and co-workers[35] on $10 \mu \mathrm{M} \mathrm{Fe-citrate} \mathrm{at}$ $20{ }^{\circ} \mathrm{C}$ under continuous light from fluorescent tubes (7 $\mu \mathrm{mol} \mathrm{m}-2 \mathrm{~s}-1)$. For the inhibition growth assays, the microorganisms were transferred into commercial 96well microtiter plates endowed with $180 \mu \mathrm{ll}$ cyanobacterial medium or $180 \mu \mathrm{l}$ Fe-limited cyanobacterial medium ( $0.1 \mu \mathrm{M}$ Fe-citrate). $20 \mu \mathrm{l}$ cell suspension were added to each well having then an OD675 nm of approximately 0.1 at the beginning of the experiment. The plates were incubated at $20^{\circ} \mathrm{C}$ under continuous light from fluorescent tubes $\left(7 \mu \mathrm{mol} \mathrm{m} \mathrm{m}^{-2} \mathrm{~s}^{-1}\right)$. Measurements of $\mathrm{OD}_{675} \mathrm{~nm}$ were performed daily on an Absorbance Microplate Reader (Spectra Max 190; Molecular Devices Corporation; Sunnyvale, CA, USA). Anachelin, the synthesised fragments, and the diastereoisomers were added on the $5^{\text {th }}$ day in $20 \mu \mathrm{l}$ dissolved in $\mathrm{H}_{2} \mathrm{O}$. Each compound was tested in five to six concentrations, ranging from $8 \mathrm{nM}$ to $90 \mu \mathrm{M}$ (end concentrations in the wells). The $\mathrm{OD}_{675} \mathrm{~nm}$ was chosen for the determination of the in vivo absorption of chlorophyll a. To test the validity of this method, dilutions were prepared ranging from an $\mathrm{OD}_{675} \mathrm{~nm}$ of 0.01 to $1.2(\mathrm{M}$. aeruginosa) and of 0.01 to 1.8 ( $\mathrm{K}$. contorta). The $\mathrm{R}^{2}$ values of the linear regression curves were 0.998 and 0.999 respectively.

\section{REFERENCES}

G. P. Falkowski, R. T. Barber, V. Smetacek, 'Biogeochemical Controls and Feedbacks on Ocean Primary Production' Science 1998, 281, 200-206.

[2] E. M. Gross, 'Allelopathy of Aquatic

Autotrophs', Crit. Rev. Plant Sci. 2003, 22, 313339.

[3] M. J. Behrenfeld, A. J. Bale, Z. S. Kolber, J. Aiken, P. G. Falkowski, 'Confirmation of iron limitation of phytoplankton photosynthesis in the equatorial Pacific Ocean', Nature 1996, 383,

508-511. 
[4] A. Butler, 'Acquisition and Utilization of Transition Metal lons by Marine Organisms', Science 1998, 281, 207-210.

[5] D. A. Hutchins, A. E. Witter, A. Butler, G. W. Luther, 'Competition among marine phytoplankton for different chelated iron species' Nature 1999, 400, 858-861.

[6] J. B. Neilands, 'Microbial Iron Compounds', Annu. Rev. Biochem. 1981, 50, 715-731.

[7] A. Imai, T. Fukushima, K. Matsushige, 'Effects of iron limitation and aquatic humic substances on the growth of Microcystis aeruginosa' Can. J. Fish. Aquat. Sci. 1999, 56, 1929-1937.

[8] S. J. Goldman, P. J. Lammers, M. S. Berman, J.J. Sanders-Loehr, 'Siderophore-mediated iron uptake in different strains of Anabaena sp.' $J$. Bacteriol. 1983, 156, 1144-1150; S. W. Wilhelm, C.G. Trick, 'Iron-limited growth of cyanobacteria: Multiple siderophore production is a common response' Limnol. Oceanogr. 1994, 39, 1979-1984; S. W. Wilhelm, D. P. Maxwell, C.G. Trick,' Growth, iron requirements, and siderophore production in iron-limited Synechococcus PCC 7002' Limnol. Oceanogr. 1996, 41, 89-97.

[9] Review: P. N. Leão, N. Engene, A. Antunes, W. H. Gerwick, V. Vasconcelos, 'The chemical ecology of cyanobacteria', Nat. Prod. Rep.

2012, 29, 372-391.

[10] K. A. Hunter, P. W. Boyd, 'Iron-binding ligands and their role in the ocean biogeochemistry of iron', Environ. Chem. 2007, 4, 221-232.

[11] G.E. Fogg, D. F. Westlake,' The Importance of extracellular products of algae in freshwater', Verh. Int. Ver. Theoret. Angew. Limnol. 1955, 12, 219-232.

[12] M. Tassigny, M. Lefèvre, 'Auto., heteroantagonisme et autres consequences des excretions d'algues d'eau douce ou thermale', Mitt. Int. Ver. Theor. Angew. Limnol. 1971, 19, 26-38.

[13] T. P. Murphy, D. R. Lean, C. Nalewajko, 'Biotic interactions between different species of algae', Science 1976, 192, 900-902.
[14] C. J. Matz, M. R. Christensen, A. D. Bone, C. D. Gress, S. B. Widenmaier, H. G. Weger, 'Only iron-limited cells of the cyanobacterium Anabaena flos-aquae inhibit growth of the green alga Chlamydomonas reinhardtii' Can. J. Bot. 2004, 82, 436-442.

[15] a) H. Beiderbeck, K. Taraz, H. Budzikiewicz, 'Anachelin, the siderophore of the cyanobacterium Anabaena cylindrica CCAP 1403/2A', Z. Naturforsch. C 2000, 55, 681-687;

b) Y. Itou, S. Okada, M. Murakami, 'Two structural isomeric siderophores from the freshwater cyanobacterium Anabaena cylindrica (NIES-19)', Tetrahedron 2001, 57, 9093-9099; c) Y. Ito, K. Ishida, S. Okada, M. Murakami, 'The absolute stereochemistry of anachelins, siderophores from the cyanobacterium Anabaena cylindrica' Tetrahedron 2004, 60, 9075-9080.

[16] K. Gademann, H. Budzikiewicz, 'The peptide alkaloid anachelin: NMR spectroscopic evidence for $\beta$-turn formation in aqueous solution', Chimia 2004, 58, 212-214.

[17] K. Gademann, Y. Bethuel, 'A Biomimetic Route to the Peptide Alkaloid Anachelin', Angew. Chem. Int. Ed. 2004, 43, 3327-3329.

[18] K. Gademann, Y. Bethuel, H. H. Locher, C. Hubschwerlen, 'Biomimetic Total Synthesis and Antimicrobial Evaluation of Anachelin H' J. Org. Chem. 2007, 72, 8361-8370.

[19] K. Gademann, Y. Bethuel, 'Total Synthesis of Anachelin H' Org. Lett. 2004, 6, 4707-4710.

[20] P. Garner, J. M. Park, '1,1,-Dimethylethyl (S)or $(R)$-4-formyl-2,2-dimethyl-3oxazolidinecarboxylate: A useful serinal derivative' Org. Synth. 1992, 70, 18-24.

[21] a) A. Hafner, R. O. Duthaler, R. Marti, G. Rihs, P. Rothe-Streit, F. Schwarzenbach, 'Enantioselective syntheses with titanium carbohydrate complexes. Part 7. Enantioselective allyltitanation of aldehydes with cyclopentadienyldialkoxyallyltitanium complexes' J. Am. Chem. Soc. 1992, 114 2321-2336; b) A. Dubey, A. Harbindu, P. 
Kumar, 'Stereoselective Synthesis of (-)Galantinic Acid' Synthesis 2011, 901-904.

[22] H. Jiang, B. Gschwend, L. Albrecht, K. A. Jørgensen, 'Organocatalytic Preparation of Simple $\beta$-Hydroxy and $\beta$-Amino Esters: Low Catalyst Loadings and Gram-Scale Synthesis' Org. Lett. 2010, 12, 5052-5055.

[23] M. Marigo, J. Franzén, T. B. Poulsen, W. Zhuang, K. A. Jørgensen, 'Asymmetric Organocatalytic Epoxidation of $\alpha, \beta$-Unsaturated Aldehydes with Hydrogen Peroxide', J. Am. Chem. Soc. 2005, 127, 6964-6965.

[24] K. Y.-K. Chow, J. W. Bode, 'Catalytic Generation of Activated Carboxylates: Direct, Stereoselective Synthesis of $\beta$-Hydroxyesters from Epoxyaldehydes', J. Am. Chem. Soc. 2004, 126, 8126-8127.

[25] T. Nagai, A. Imai, K. Matsushige, T. Fukushima, 'Growth characteristics and growth modeling of Microcystis aeruginosa and Planktothrix agardhii under iron limitation' Limnology 2007, 8, 261-270.

[26] S. Schubert, D. Fischer, J. Heesemann, 'Ferric Enterochelin Transport in Yersinia enterocolitica: Molecular and Evolutionary Aspects', J. Bacteriol. 1999, 181, 6387-6395.

[27] A. D'Onofrio, J. M. Crawford, E. J. Stewart, K. Witt, E. Gavrish, S. Epstein, J. Clardy, K. Lewis, 'Siderophores from Neighboring Organisms Promote the Growth of Uncultured Bacteria' Chem. Biol. 2010, 17, 254-264.

[28] C.D. Moon, X.-X. Zhang, S. Matthijs, M. Schäfer, H. Budzikiewicz, P. B. Rainey,' Genomic, genetic and structural analysis of pyoverdine-mediated iron acquisition in the plant growth-promoting bacterium Pseudomonas fluorescens SBW25' BMC Microbiol. 2008, 8, 7-19.

[29] G. McDonnell, A. D. Russell, 'Antiseptics and disinfectants: activity, action, and resistance', Clin. Microbiol. Rev. 1999, 12, 147-179; K. Vasilev, J. Cook, H. J. Griesser,' Antibacterial surfaces for biomedical devices', Expert. Rev. Med. Dev. 2009, 6, 553-567.
[30] S. Sánchez-Fortún, F. Marvá, A. D’ors, E. Costas, 'Inhibition of growth and photosynthesis of selected green microalgae as tools to evaluate toxicity of dodecylethyldimethylammonium bromide', Ecotoxicology 2008, 17, 229-234; D. van Wijk, M. Gyimesi-van den Bos, I. Garttener-Arends, M. Geurts, J. Kamstra, P. Thomas, 'Bioavailability and detoxification of cationics: I. Algal toxicity of alkyltrimethyl ammonium salts in the presence of suspended sediment and humic acid' Chemosphere 2009, 75, 303-309.

[31] A. C. Jones, E. A. Monroe, E. B. Eisman, L. Gerwick, D. H. Sherman, W. H. Gerwick, 'The unique mechanistic transformations involved in the biosynthesis of modular natural products from marine cyanobacteria', Nat. Prod. Rep. 2010, 27, 1048-1065.

[32] H. Bickel, E. Gaumann, W. Keller-Schierlein, V. Prelog, E. Vischer, A. Wettstein, H. Zähner, 'Über eisenhaltige Wachstumsfaktoren, die Sideramine, und ihre Antagonisten, die eisenhaltigen Antibiotika Sideromycine', Experientia 1960, 16, 129-133; F. Knüsel, J. Nüesch, 'Mechanism of action of sideromycins', Nature 1965, 206, 674-676; V. Braun, M.

Braun, M., 'Active transport of iron and siderophore antibiotics' Curr. Opin. Microbiol. 2002, 5, 194-201. For a review on natural product hybrids, see L. F. Tietze, H. P. Bell, S. Chandrasekhar,' Natural product hybrids as new leads for drug discovery', Angew. Chem. Int. Ed. 2003, 42, 3996-4028.

[33] E. A. Crane, K. Gademann,' Capturing Biological Activity in Natural Product Fragments by Chemical Synthesis' Angew. Chem. Int. Ed. Engl. 2016, 55, 3882-3902.

[34] For our work in this area, see: E. Kohler, V. Grundler, D. Häussinger, R. Kurmayer, K. Gademann, J. Pernthaler, J. F. Blom, 'The toxicity and enzyme activity of a chlorine and sulfate containing aeruginosin isolated from a non-microcystin-producing Planktothrix strain' Harmful Algae 2014, 39, 154-160; K. Gademann, C. Portmann, J. F. Blom, M. Zeder, 
F. Jüttner, 'Multiple toxin production in the cyanobacterium Microcystis: Isolation of the toxic protease inhibitor cyanopeptolin 1020', J. Nat. Prod. 2010, 73, 980-984; C. Portmann, J. F. Blom, M. Kaiser, R. Brun, F. Jüttner, K.

Gademann,' Isolation of Aerucyclamides $C$ and $D$ and Structure Revision of Microcyclamide 7806A: Heterocyclic Ribosomal Peptides from Microcystis aeruginosa PCC 7806 and Their Antiparasite Evaluation' J. Nat. Prod. 2008, 71, 1891-1896; C. Portmann, J. F. Blom, K.

Gademann, F. Jüttner, 'Aerucyclamides $A$ and

$B$ : isolation and synthesis of toxic ribosomal heterocyclic peptides from the cyanobacterium Microcystis aeruginosa PCC 7806', J. Nat.

Prod. 2008, 71, 1193-1196.

[35] F. Jüttner, J. Leonhardt, S. Möhren,

'Environmental Factors Affecting The Formation

Of Mesityloxide, Dimethylallylic Alcohol And

Other Volatile Compounds Excreted By

Anabaena cylindrica' J. Gen. Microbiol. 1983,

129, 407-412. 
Entry for the Table of Contents

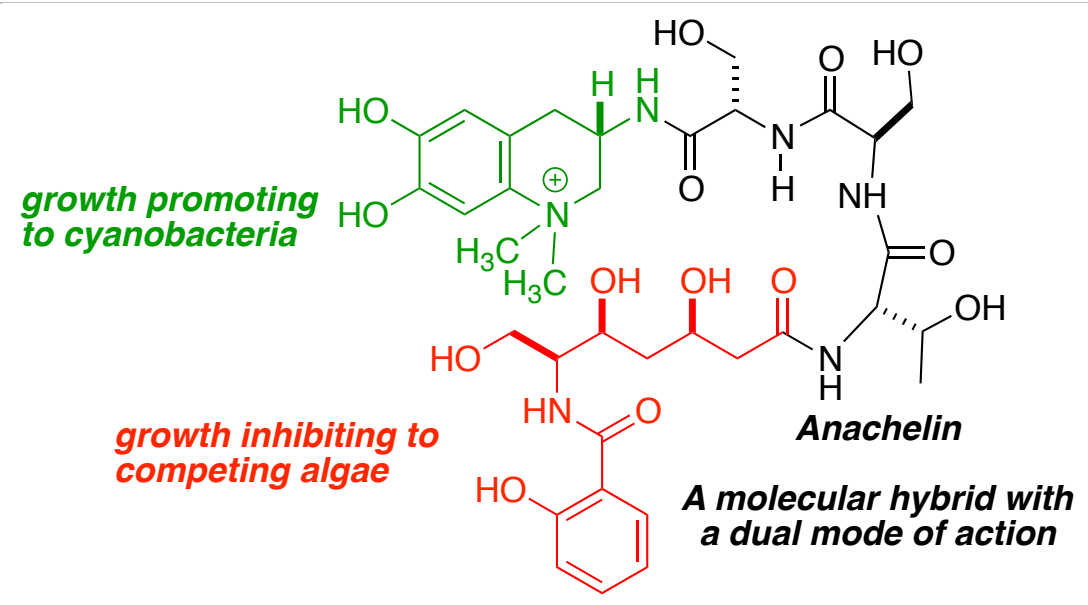

